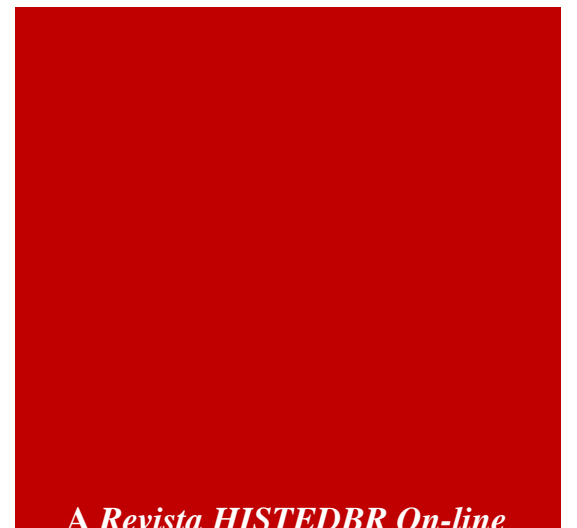

A Revista HISTEDBR On-line publica artigos resultantes de estudos e pesquisas científicas que abordam a educação como

fenômeno social em sua vinculação com a reflexão histórica

Correspondência ao Autor

Nome: Kevin Daniel dos Santos

Leyser

E-mail: kevinleyser@gmail.com

Centro Universitário Leonardo

Da Vinci, Brasil

Submetido: 03/07/2018

Aprovado: 27/11/2018

Publicado: 19/03/2019

doi> 10.20396/rho.v19i0.8652858

e-Location: e019004

ISSN: 1676-2584

\section{FILOSOFIA LATINO-AMERICANA E O \\ PRAGMATISMO NORTE-AMERICANO: O \\ PENSAMENTO DE VAZ FERREIRA}

\title{
RESUMO
}

Este artigo visa a identificar e descrever o diálogo e as conexões existentes entre o pragmatismo norte americano e a filosofia latinoamericana. Deste modo, exploramos especificamente a produção teórica de Carlos Vaz Ferreira, do Uruguai, enfatizando os pontos de contato, de influência e de diálogo com o pragmatismo norteamericano. As intersecções entre o pensamento destes autores apontam para o desenvolvimento de ambas tradições como não sendo isoladas uma da outra. Isto é, é possível constatar, ainda que de maneira limitada, que há pontos de intersecção entre desenvolvimentos lineares na história dessas tradições filosóficas e que estudar estes pontos evidencia que no diálogo entre as tradições de pensamento nas Américas manifesta-se a preocupação, por exemplo, com a experiência vivida prática, o anti-cartesianismo, o falibilismo e o pluralismo. Estas preocupações possibilitam uma contribuição profícua para pensarmos a educação.

PALAVRAS-CHAVE Carlos Vaz Ferreira. Filosofia latino-americana. Pragmatismo norte-americano. Educação. 


\title{
Revista HIISTEDIBR On-line

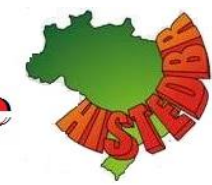 \\ THE LATIN AMERICAN PHILOSOPHY AND NORTH AMERICAN PRAGMATISM: THE THOUGHT OF VAZ FERREIRA
}

\begin{abstract}
This article aims to identify and describe the dialogue and connections between North American Pragmatism and Latin American Philosophy. In this way, we specifically explore the theoretical production of Carlos Vaz Ferreira from Uruguay, emphasizing points of contact, influence and dialogue with North American Pragmatism. The intersections between the thought of these author point to the development of both traditions as not being isolated from each other. That is, it is possible to observe, although in a limited way, that there are points of intersection between linear developments in the history of these philosophical traditions, and that to study these points shows that in the dialogue among the traditions of thought in the Americas the concern with practical lived experience, antiCartesianism, fallibilism and pluralism, for example. These concerns make a fruitful contribution to thinking about education.
\end{abstract}

Keywords: Carlos Vaz Ferreira. Latin american philosophy. North american pragmatism. Education.

\section{LA FILOSOFÍA LATINOAMERICANA Y EL PRAGMATISMO NORTEAMERICANO: EL PENSAMIENTO DE VAZ FERREIRA}

\begin{abstract}
Resumen
Este artículo pretende identificar y describir el diálogo y las conexiones existentes entre el Pragmatismo Norteamericano y la Filosofía Latinoamericana. De este modo, exploramos específicamente la producción teórica de Carlos Vaz Ferreira, de Uruguay, enfatizando los puntos de contacto, de influencia y de diálogo con el Pragmatismo Norteamericano. Las intersecciones entre el pensamiento de estos autores apuntan al desarrollo de ambas tradiciones como no aisladas una de la otra. Esto es, es posible constatar, aunque de manera limitada, que hay puntos de intersección entre desarrollos lineales en la historia de esas tradiciones filosóficas y que estudiar estos puntos pone de manifiesto que en el diálogo entre las tradiciones de pensamiento en las Américas se manifiesta la preocupación, por ejemplo, con la experiencia vivida práctica, el anti-cartesianismo, el falibilismo y el pluralismo. Estas preocupaciones posibilitan una contribución provechosa para pensar la educación.
\end{abstract}

Palabras claves: Carlos Vaz Ferreira. Filosofía latinoamericana. Pragmatismo Norteamericano. Educación. 


\section{INTRODUÇÃO}

Autores como Browning (2011), Donoso (2011), Duran (2001), Flores (2011), Graham (1994), Gomez (2006), Kalvelage (1974), Medina (2004), Pappas (2007), entre outros tem lançado mão de pesquisas sobre as conexões históricas entre os pragmatistas norte-americanos (como Charles S. Peirce, John Dewey e William James) com pensadores latino-americanos. Há um consenso entre esses autores de que o pragmatismo teve uma audiência receptiva durante a primeira metade do século XX nas Américas. Contudo, a segunda metade do século $\mathrm{XX}$ testemunhou um eclipsar nos estudos do pragmatismo.

Visões negativas, mas equivocadas, sobre o pragmatismo como uma variedade do positivismo ou como um superficial utilitarismo de estilo americano espalharam-se através das Américas. (MENDIETA, 2001; SHOOK; MARGOLIS, 2006). Igualmente importante, entretanto, foi a recepção na América do Norte e na América Latina de movimentos filosóficos europeus, incluindo o existencialismo e a filosofia analítica. Não há duvidas de que o "giro analítico" durante os anos de 1960 sufocou os textos pragmatistas na América do Norte e na América Latina. Não foi até a publicação em 1979 do livro Philosophy and the Mirror of Nature de Richard Rorty que o interesse no pragmatismo clássico desfrutou uma ressurreição tanto na América do Norte, na América Latina e até mesmo na Europa.

Esse reavivamento do pragmatismo, portanto, não ocorreu somente na América do Norte. A Espanha, por exemplo, tem se tornado o centro de esforços mundialmente colaborativos para os hispânicos traduzirem e reavaliarem o pragmatismo como uma filosofia viável. Na última década, vários países da América Latina, como a Argentina e o Brasil, realizaram conferências centradas sobre o pragmatismo. A filosofia analítica não tem mais a influência que desfrutava sobre as Américas no século passado. Gradualmente, um ambiente mais pluralístico na filosofia está se desenvolvendo que abre a possibilidade de redescobrir os esquecidos filósofos das Américas. O fato de que ambas, as filosofias analítica e continental, estão finalmente reconhecendo a sua dívida para os pragmatistas clássicos tem ajudado nesta redescoberta. (ABOULAFIA, 2002; BRANDON, 2000).

Pappas (2011) argumenta que seria um erro pensar no desenvolvimento do pragmatismo e da filosofia latino-americana como isoladas uma da outra. Há pontos de intersecção entre desenvolvimentos lineares na história das tradições filosóficas, estudar estes pontos de intersecção pode render importantes lições. Lições que podem ampliar e gerar perspectivas filosóficas profícuas possibilitando novos rumos para as interfaces de áreas do conhecimento, como por exemplo, a filosofia e a educação.

Os trabalhos de William James e Ralph Emerson foram lidos na América Latina na virada do século XX. (INGENIEROS, 1947, 1963; VAZ FERREIRA, 1909a). As suas ideias tiveram um impacto em pensadores importantes no mundo hispânico, inclusive Miguel de Unamuno (MARTÍNEZ, 2007), Ortega y Gasset, Eugenio d'Ors, José Ingenieros, e Carlos Vaz Ferreira. Este último, pensador latino-americano, desenvolveu em seu diálogo com o 
pragmatismo uma filosofia própria e original. A seguir, descreveremos elementos desse diálogo, aspectos de sua filosofia latino-americana, expondo suas contribuições profundas para se pensar questões como o ser humano, a epistemologia e a ontologia; o conhecimento, a linguagem e a realidade, questões centrais nas intersecções entre tradições filosóficas e entre a filosofia e a educação.

\section{CARLOS VAZ FERREIRA: LEITOR E CRÍTICO DO PRAGMATISMO}

De acordo com Pérez-Ilzarbe (2011) o filósofo uruguaio e educador Carlos Vaz Ferreira (1872-1958) foi um dos primeiros latinos que leu sobre o pragmatismo. Ele introduziu as ideias de William James em seu país e criticamente as revisou. Em 1909 Vaz Ferreira publicou El Pragmatismo, o primeiro livro em espanhol dedicado ao pragmatismo. (NUBIOLA; ZALAMEA, 2006). Essa coletânea de palestras, oferecidas em 1908, foram traduzidas para o francês em 1914, dando, portanto, às ideias de Vaz uma presença internacional. O próprio Albert Einstein chegou a ler essa tradução e em uma carta a Vaz Ferreira demonstrou estar de acordo com certos pontos. (VAZ FERREIRA, 1965) ${ }^{3}$. Como declarado nas primeiras páginas do livro, o pragmatismo de Vaz considera e critica a filosofia de William James pois, de acordo como Vaz Ferreira, James é "[...] o sustentador mais brilhante e popular da doutrina." (VAZ FERREIRA, 1963a, p. 85-86, tradução nossa).

Alguns anos antes, Vaz tinha escrito dois outros trabalhos dedicados aos escritos de James: Conocimiento y acción (VAZ FERREIRA, 1963a), depois de ler o The Will do Believe (JAMES, 1897); e En los márgenes de "L'Experience Réligieuse" de William James (VAZ FERREIRA, 1908), uma coletânea das anotações de Vaz de sua leitura da tradução francesa do The Varieties of Religious Experience. (JAMES, 1902). A despeito do caráter crítico desses três trabalhos, James era de fato um dos filósofos favoritos de Vaz; sua presença no pensamento de Vaz é reconhecida em vários lugares. Vaz particularmente louva o capítulo IX do The Principles of Psychology (JAMES, 1950) por uma concepção do pensamento da qual ele aprova completamente. (ROMERO BARÓ, 1993; MALVASIO, 1996; CAMPOS, 1959).

Apesar da reputação doméstica de Vaz Ferreira como um pensador original (ARDAO, $1956)^{4}$, a sua filosofia permaneceu relativamente desconhecida fora do mundo latino. Esta é uma das razões pelas quais as conexões de Vaz com o pragmatismo podem parecer inusitadas. A outra razão é que Vaz na realidade recusou ser chamado de pragmatista no sentido estrito. Contudo, o seu pensamento foi influenciado e de algumas maneiras expandiu o pragmatismo. A despeito de algumas de suas críticas às ideias de James e do pragmatismo em geral, o pensamento de Vaz Ferreira está muito próximo dos problemas e abordagens características do pragmatismo norte-americano.

\section{TENDÊNCIAS POSITIVAS, NEUTRAS E NEGATIVAS DO PRAGMATISMO}

\begin{tabular}{l|l|l|l|l|l} 
(C) Rev. HISTEDBR On-line & Campinas, SP & v.19 & $1-26$ & $\mathrm{e} 019004$ & 2019
\end{tabular} 
Depois de oferecer a revisão crítica sobre a teoria da verdade de James, Vaz no livro $E l$ pragmatismo (1909a) finaliza com um louvor ao pragmatismo, considerando-o como um conjunto de "tendências". Vaz distingue algumas tendências positivas às quais ele acolhe totalmente. Algumas tendências neutras que se tornam em negativas quando são aplicadas erroneamente e algumas tendências decididamente negativas que ele deseja resistir em seu próprio pensamento. (VAZ FERREIRA, 1963a). As tendências negativas que Vaz identifica como comuns ao movimento pragmatista são a desvalorização da razão de James e o seu abandono das ideias que não possuem consequências práticas significantes. As tendências neutras, mas perigosas, identificadas por Vaz Ferreira são a introdução das emoções nas questões teóricas e o interesse nas consequências práticas de qualquer teoria. Estas são negativas na medida em que bloqueiam o reconhecimento de uma verdade não relativa.

Podemos ver exemplos destas tendências em que William James (1897) de fato defendeu algumas visões distintas e controversas sobre os padrões normativos que devem ser adotados quando estamos refletindo sobre o que devemos acreditar. Ele sustenta que, em certos tipos especiais de casos, é racional acreditar em proposições, mesmo que tenhamos pouca ou nenhuma evidência para sustentar nossas crenças. E, nesses casos, ele sustenta que nossas crenças podem ser determinadas pelo que ele chama de "considerações passionais" que incluem medo e esperança, preconceito e paixão, imitação e partidarismo, entre outras disposições. James também conclui que quando a coisa é uma ideia o seu mérito volta-se para “[...] qual diferença definitiva esta fará para você̂ e eu." (JAMES, 1987a, p. 508, tradução nossa). Neste caso, as concepções vão além de relatos de efeitos concebíveis para incluir o que constitui efeitos preferíveis. Por considerar uma coisa em termos de seu "valor-efetivo", James pensa que se obtêm uma medida de valor relativo. Coisas com maior "valor-efetivo", isto é, coisas que possuem mais efeitos valorativos, se tornam coisas preferidas em escolher ações e buscar possibilidades. Esses efeitos preferíveis, então, se tornam normativos de nossa concepção das coisas e eventos. Contudo, aceitar essa visão do conhecimento parece nos conduzir a aceitar uma espécie de sofisma no qual os interesses humanos tornam-se reais a medida do que constitui o conhecimento. A visão está fadada a ter problemas, pois o "conhecimento" não teria nenhuma conexão confiável com as coisas e eventos na medida em que agradam ou falham em agradar os seres humanos. O que nós sabemos seria somente uma questão de "desejo", com pouca relação ao que é "real" ou "verdade".

Perante estas tendências, Vaz Ferreira estava interessado em que o pragmatismo não se tornasse uma filosofia que encorajasse o irracionalismo e o relativismo. Ele, então, desenvolveu uma concepção da relação entre humanos, linguagem, realidade e conhecimento que evita aqueles perigos.

Em seu reconhecimento de certas tendências positivas do pragmatismo, Vaz mostra um profundo acordo que subjaz os desacordos com James. Ele lista: (1) a liberação do pensamento da dominação da linguagem; (2) a preferência do concreto e não do abstrato; (3) o 
interesse nos problemas das experiências humanas vividas; e (4) a atitude respeitosa com as ideias e sentimentos diferentes daqueles que sejam seus próprios. (VAZ FERREIRA, 1909a).

Vaz Ferreira contrasta o pragmatismo de James com a atitude de J. S. Mill a qual Vaz considera "pragmatista" de alguma maneira, mas que ele se recusa chamá-la por esse termo no sentido estrito. Essa atitude encontra um caminho intermediário entre o racionalismo estrito e o irracionalismo: "Essa é a atitude correta. A razão não é tudo: razão, complementada pela emoção e imaginação, mas nunca forçada nem corrompida nem desprezada." (VAZ FERREIRA, 1963a, p. 186, tradução nossa).

Essa atitude é de fato o núcleo da filosofia própria de Vaz, nomeadamente: a razão não é absoluta, mas permanece como um instrumento indispensável para nossa relação com a realidade. Deveria, portanto, ser complementada por outras dimensões não racionais de nossas interações com o mundo, mas nunca eclipsada por elas. (COSTÁBILE, 1993) $)^{5}$ A raiz da hostilidade de Vaz ao pragmatismo é uma resposta à posição anti-intelectualista radical de James, que ele neutraliza com uma defesa da razão como um auxílio valioso para penetrar na realidade. Mas a mesma tendência de equilíbrio pode ser encontrada no fundador do pragmatismo, C. S. Peirce, que também denuncia as tendências anti-intelectualistas em James. (HOOKWAY, 1997).

\section{SISTEMAS RACIONAIS E CLASSIFICAÇÕES LINGUÍSTICAS}

A filosofia de Vaz se preocupa com a relação entre seres humanos e realidade ${ }^{6}$. Os humanos são seres viventes e agentes e suas atividades necessitam ser conduzidas no interior de uma realidade vasta e complexa que excede as suas capacidades de capturá-la. A realidade, contudo, sempre permanece estranha à mente humana, sempre radicalmente diferente de qualquer apreensão humana dela.

Ao contrário das reações anti-intelectualistas e irracionalistas às crises do Positivismo, Vaz quer um lugar para a razão na vida humana, e um lugar central no entendimento humano da realidade. Ele é simplesmente bem cuidadoso de não dar a razão o acesso exclusivo à realidade. (COSTÁBILE, 1993, p. 14, tradução nossa).

A razão nos permitiu construir algumas ferramentas úteis pelas quais a realidade pode ser organizada e controlada - ao menos até certa extensão. A lógica e a linguagem são básicas entre essas ferramentas pois elas oferecem aos seres humanos a capacidade de sistematizar e classificar o mundo. Vaz compartilha com James a ideia de que a organização e o controle são obtidos com um alto custo: os sistemas racionais e classificações somente dividem o continuum, simplificam o complexo, e reduzem o ilimitado a um tamanho prático, perdendo, portanto, as riquezas da realidade. A razão, no sentido estrito, é rígida e estática, enquanto que a realidade é um fluxo e um movimento.

James de fato observa, a despeito de um preconceito filosófico antigo em relação a perceber as conexões entre as coisas, que é também possível atender à desunião ou separação. 
"Se nosso intelecto tivesse sido tão interessado em relações disjuntivas assim como o é em conjuntivas, a filosofia teria igualmente com sucesso celebrado a desunião do mundo." (JAMES, 1987a, p. 546, tradução nossa). O ponto não é que a diversidade é para ser vista como mais fundamental do que a unidade, mas que "[...] nem é primordial ou mais essencial ou excelente do que a outra.” (JAMES, 1987a, p. 546, tradução nossa).

O compromisso ao pluralismo torna claro tanto uma ruptura do que James via como a tradição filosófica, quanto um interesse explícito em perceber e até promover a diferença. James (1987a, p. 546, tradução nossa) sintetiza

[...] assim como com o espaço, cuja separação das coisas aparenta exatamente a par com a sua unidade destas, mas às vezes uma função e às vezes a outra é o que chega na maioria das vezes à nós, então, em nossa maneira geral de lidar com o mundo das influências, nós às vezes precisamos condutores e às vezes precisamos nãocondutores, e a sabedoria está em saber qual é qual no momento apropriado.

Usar a metáfora do espaço, oferece tanto um meio de marcar a diferença e uma base para a conexão. James argumenta que nós precisamos reconhecer tanto a diferença quanto a conexão na experiência e estar preparado para concentrar-se em uma ou no outra ou em ambas, dependendo das circunstâncias.

Para James, o compromisso com este tipo de interação necessariamente traz um compromisso ao pluralismo epistêmico. Neste caso, o pluralismo implica "[...] um mundo de constituição aditiva [...]", ou seja, um mundo que é incompleto. (JAMES, 1987a, p. 558, tradução nossa). A interação no mundo revela a possibilidade de "outro conhecimento" desde o início. "O próprio fato que debatemos esta questão mostra que nosso conhecimento é incompleto no presente e sujeito a adição.” (1987a, p. 558, tradução nossa).

Esse caráter do conhecimento, contudo, faz demandas também sobre as nossas expectativas sobre o mundo. "Em relação ao conhecimento que o contêm o mundo muda e cresce genuinamente [...]”, então o pluralismo epistemológico pragmático implica um pluralismo ontológico também. (JAMES, 1987a, p. 559, tradução nossa). O status dessa ontologia, contudo, permanece em si mesmo "pragmático" e sujeito a efeitos que mudam. "O pragmatismo", conclui James, "[...] aguardando o apuramento empírico final do que exatamente o equilíbrio da união e desunião entre as coisas podia ser, deve obviamente enfileirar-se do lado pluralístico." (JAMES, 1987a, p. 556, tradução nossa). Assim como ele diz no início de sua coletânea The Will to Believe: "Prima facie o mundo é um pluralismo; como o encontramos, a sua unidade parece ser aquela de qualquer conjunto; e nosso pensamento superior consiste principalmente de um esforço para o redimir de sua primeira forma bruta." (JAMES, 1897, p. viii, tradução nossa). Depois, em seu livro postumamente publicado, Some Problems of Philosophy, ele conclui, "[...] para sintetizar, o mundo é 'um' em alguns aspectos, e 'muitos' em outros.” (JAMES, 1987b, p. 1049, tradução nossa).

Vaz dedica longos parágrafos à chamada lei da unidade. Ele expressa que o Universo é uno, é conexo e o conhecimento que se deve ter dele deveria ter a mesma característica. 
Portanto, ao ponderar sobre a educação, para o filósofo uruguaio, nos assuntos ensinados deveria haver unidade de doutrina. A lei da unidade pede que não haja conteúdos desconectados, princípios discordantes, diferença de critérios recomendados. Diante dessas considerações, Vaz (1963b, v. 12, p. 190-191, tradução nossa) diz:

\begin{abstract}
Efetivamente: o Universo deve ser uno e conexo. Devemos supor que o seria para uma inteligência absoluta e infalível; que o seria, por exemplo, para um deus. Quanto ao homem, certamente deve buscar, deve conceber como o ideal supremo do conhecimento, esse conhecimento em que nada é contraditório, que nada é desconexo, em todas as verdades, como dizem aqui, correspondem e ajustam-se umas nas outras da maneira mais absoluta. Não sei se esse ideal será possível. Eu não acredito. Mas até mesmo aqueles que acreditam, reconhecem e sabem que este não é o nosso conhecimento real; que não é isso, portanto, o conhecimento que possuímos e o conhecimento que somos capazes de transmitir. Já foi dito, em uma das sentenças mais antigas do mundo: A medida, precisamente, que sabemos mais, percebemos melhor e sentimos mais profundamente a impressão de nossa quase total ignorância.
\end{abstract}

Perante esta realidade, Vaz sugere que "[...] o modo menos ruim de educar, o menos imperfeito, é ensinar a criança ou ao homem, quem quer que seja ensinado, o que é precário em nosso conhecimento; não esconda, nunca esconda essas lacunas". O pensador uruguaio afirma que devemos mostrar aos alunos as contradições que existem entre os diferentes elementos do nosso conhecimento fragmentado e pobre, nunca as disfarçar. "Nosso conhecimento sobre o Universo é desconexo, fragmentário, mais ou menos contraditório às vezes. Se esse caráter for perdido, ele é falsificado, reduzido ou desnaturalizado." (VAZ FERREIRA, 1963b, v. 12, p. 191-192, tradução nossa).

Contudo, contrabalançando a tendência natural do espírito humano de sistematizar - o que pode ser profícuo quando aplicado corretamente - Vaz nos lembra dos limites de qualquer sistema. Primeiro, um sistema não é idêntico com as coisas que esboça ${ }^{7} \mathrm{e}$, portanto, nunca pode substituir a própria realidade que se lhe escapa. Segundo, os sistemas não podem ser aplicados a qualquer realidade que precisamos lidar, pois cada situação concreta é única, e, portanto, nunca poderemos forçar a realidade em um sistema pré-estabelecido. Dois dos perigos que Vaz Ferreira denuncia repetidamente são: a "transcendentalização" - a atribuição para a realidade do que pertence ao nosso discurso sobre ela, e "pensar por sistemas" - o uso de uma fórmula pré-existente ao invés de abordar cada problema concreto em si mesmo. (VAZ FERREIRA, 1963b) ${ }^{8}$. Esses são muito próximos do que Dewey chamava de "[...] a falácia filosófica [...]" (DEWEY, 1981, p. 51, tradução nossa) quando filósofos usam os produtos de suas investigações para substituir a riqueza da experiência da forma como ela é vivida. De acordo com Vaz, esses últimos perigos podem ser evitados se nós refletirmos sobre a função própria e natureza da razão.

\title{
RAZONABILISMO: ELEMENTOS RACIONAIS, EMOCIONAIS E INSTINTIVOS
}


Os sistemas e as classificações são ferramentas que não devem ser tomadas como fotografias fiéis da realidade. A realidade é contínua e gradual, enquanto que as classificações a dividem artificialmente. A linguagem é um sistema que depende da classificação: atribuir um predicado a um sujeito é situá-lo sob um esquema simplificado. Novamente, esse procedimento tem se demonstrado muito útil, mas a realidade sempre permanecerá além de qualquer simplificação. Em diversos lugares Vaz Ferreira comenta as diferenças entre coisas reais, que "são como elas são", e qualquer descrição humana dessas. (VAZ FERREIRA, $1963 b)^{9}$.

Uma formulação linguística, mesmo sendo bem detalhada e concreta, é somente uma representação esquemática da coisa real que alguém está tentando descrever. Quanto mais geral é uma representação mais imperfeita ela se torna. É por essa razão que quando falamos de qualquer coisa em termos gerais quase que inevitavelmente terminamos em uma descrição caleidoscópica da coisa, o que pode levar a ilusão de que a coisa em si mesma está mudando e enganando. Esse é um perigo que vem da própria natureza da linguagem que é composta de moldes rígidos que são essencialmente inadequados para expressar a realidade fluente.

Os sistemas racionais e classificações linguísticas precisam ser vistos como ferramentas que são muito úteis como guia para abordar a realidade. Contudo, muito perigosos se tomados como substitutos para ela. A razão, se deixada sozinha, tende a se prender nessa armadilha. É por isso que Vaz Ferreira põe uma grande carga de valor nos aspectos nãoracionais na conexão humana com a realidade, e na cooperação entre todas as faculdades humanas. Aqui, o pensador uruguaio trilha o mesmo caminho que os "filósofos da vida" que ele toma como inspiração, especialmente Bergson. O filósofo francês deixa claro em seus escritos que para abarcar o real seria necessário abordagens diferenciadas daquela da mera razão estrita. Ele afirma

Como seria mais instrutiva uma metafísica verdadeiramente intuitiva que seguisse todas as ondulações do real! Ela não mais abarcaria de uma só vez a totalidade das coisas, mas de cada uma ela daria uma explicação que se adaptaria exatamente, exclusivamente a ela. Não começaria por definir ou descrever a unidade sistemática do mundo: quem sabe se o mundo é efetivamente uno? Somente a experiência poderá dizê-lo, e a unidade, se ela existe, aparecerá ao termo da pesquisa como resultado; impossível colocá-lo no início como um princípio. (BERGSON, 1984, p. 113-114).

Vaz, seguindo esta inspiração, postula uma faculdade que ele às vezes chama racionalidad - em contraste com as visões estreitas da "inteligência" - que inclui:

[...] razão no sentido estrito - a razão raciocínio, mais o instinto lógico, e também a resistência a sugestões, a resistência a imitação, e uma quantidade mais de aptidões e resistências: um número de faculdades: algumas de recepção, algumas outras, eu insisto, de resistência, que formam aquela capacidade do senso crítico, ao mesmo tempo racional, instintivo, e também emocional. (VAZ FERREIRA, 1963b, v. 11-12, p. 149 , tradução nossa) ${ }^{10}$. 
Contra formas estritas e estreitas de racionalismo, Vaz Ferreira está convicto que existem formas distintas de se abordar a realidade. Em particular, ele enfatiza o papel desempenhado pelas capacidades não-racionais na construção de uma compreensão plástica do mundo. O pensamento possui aspectos que excedem o estritamente racional, e devem ser permitidos em uma explicação mais adequada do conhecimento humano. Vaz usa a palavra psiqueo para se referir àquele momento do pensamento que no qual o espírito humano não está dividido e é capaz de aplicar todas as suas capacidades - racionais e emocionais - ao entendimento do mundo. (GARCÍA, 1989).

A noção de psiqueo mostra a afinidade de Vaz com as ideias de William James e Henri Bergson. O termo psiqueo de Vaz aproxima-se da ideia de um "fluxo do pensamento" de James, pois ambos se opõem a uma concepção descontínua do pensamento que emerge de uma identificação errônea do pensamento com a linguagem. James (1950) se propõe a oferecer uma explicação mais rica da experiência do que as dos empiristas tradicionais como Hume. Ele acredita que relações e tendências são experimentadas diretamente, uma visão que ele defenderia mais tarde como parte de seu empirismo radical. James pensa que a consciência é um fluxo e não uma sucessão de ideias. Nossa vida psíquica tem ritmo, é uma série de transições e locais de descanso, de "voos e pousos". (JAMES, 1950, p. 236, tradução nossa). Nossa capacidade de atenção a uma coisa e não a outra é para James o sinal de um "[...] elemento ativo em toda consciência, [...] algo espiritual [...] que parece sair para encontrar essas qualidades e conteúdos, enquanto eles parecem vir para ser recebidos por ela." (JAMES, 1950, p. 285, tradução nossa). Diante da tensão entre o determinismo científico e nossa crença em nossa própria liberdade ou autonomia, James argumenta que a ciência

[...] deve ser constantemente lembrada de que seus propósitos não são os únicos propósitos e que a ordem de causalidade uniforme para a qual ela tem uso, e está correta em postular, pode ser envolvida em uma ordem mais ampla, sobre a qual ela não tem nenhuma reivindicação. (JAMES, 1950, p. 1179, tradução nossa).

Coerente com este posicionamento jamesiano, Vaz Ferreira compreende a realidade mental como fluida e contínua sem partes separadas. Portanto, ela não é expressa adequadamente pelo "[...] pensamento lógico, esquema, nem pela linguagem, esquema de um esquema." (VAZ FERREIRA, 1963b, v. 10, p. 199, tradução nossa). Vaz contrasta "pensamento por palavras" e "pensamento verdadeiro". O pensamento não-linguístico é “[...] mais ausente de forma, mas é mais plástico, vivo e levedado." Quando se está pensando com palavras obtêm-se "[...] claridade, precisão, completude, aplicação [...]", mas também se perde "[...] espontaneidade, sinceridade, vida e interesse, fertilidade." (VAZ FERREIRA, 1963b, v. 10 , p. 17, tradução nossa).

A noção de psiqueo, similar à "intuição" bergsoniana, emerge de um descontentamento similar com a habilidade da faculdade racional para apreender as riquezas da realidade - em particular, da vida. Como afirmou Bergson (1984, p. 187) 


\begin{abstract}
Em lugar de uma descontinuidade de momentos que se substituiriam num tempo indefinidamente divisível, [se] perceberá a fluidez contínua do tempo real que corre indivisível. Em lugar de estados superficiais que viriam um de cada vez recobrir uma coisa indiferente [...], [se] apreenderá uma só e mesma mudança que vai sempre se prolongando, como numa melodia onde tudo é devir mas onde o devir, sendo substancial, não necessita de suporte. [...] Uma visão deste gênero, em que a realidade aparece como contínua e indivisível, está no caminho que leva à intuição filosófica.
\end{abstract}

Do mesmo modo, para Vaz Ferreira o pensamento humano é movido não somente pela razão, mas também por uma força extrarracional que às vezes é rotulada como um instinto, às vezes como um contato intuitivo com a realidade e às vezes como um bom senso que complementa a razão pura. Esse instinto é uma condensação da experiência e da emoção que entra em jogo quando a razão por si só não é suficiente - ou seja, em toda e qualquer questão que se refere à vida real, onde "questões de graus" estão envolvidas.

Quando as formulações lógicas são inúteis, nós podemos confiar na força controladora e equilibrante do instinto que impede as sistematizações falaciosas promovendo em troca a tendência de levar em conta muitas ideias. É assim que o instinto empírico, que para Vaz é um instinto hiperlógico, vem a completar, não contrariar, os aspectos puramente lógicos do nosso pensamento e de nossas discussões. (VAZ FERREIRA, 1963b). O extrarracional se funde com o racional para alcançar uma apreensão melhor da realidade. Vaz Ferreira rotula sua própria posição de razonablismo, uma "atitude racional entendida bem amplamente", ou seja, a atitude que combina sensivelmente os elementos racionais com os emocionais e instintivos. $\mathrm{O}$ razonablismo de Vaz pode ser ilustrado examinando seu tratamento da relação entre ciência e filosofia como modalidades de pensamento diferentes, mas complementares. (VAZ FERREIRA, 1963b, v. 8, p. 26 [nota de rodapé]) ${ }^{11}$.

No contexto educacional, o filósofo uruguaio enfatiza a sua preocupação como o que ele considera um mau hábito mental: "A humanidade tem uma grande tendência - e é o seu grande mal intelectual - perceber o complementar como contraditório." (VAZ FERREIRA, 1963a, p. 135, tradução nossa). Vaz Ferreira parte da noção de que na pedagogia não existem regras absolutas, mas ideias diretas que de acordo com a circunstância adquirem um grau diferente de generalidade:

Entre essas ideias principais há duas que em parte se complementam, que em parte se opõem, e cuja importância e aplicabilidade é tão grande que, com um pouco de esforço, poderia ser concebida talvez toda a pedagogia como uma espécie de resultante, já da concordância, já do conflito dessas duas tendências. [...] Uma é a ideia diretriz (tendência ou sistema) de escalonamento. A outra é a ideia diretriz (tendência ou sistema) de penetrabilidade. (VAZ FERREIRA, 1963b, v. 17, p. 3940, tradução nossa).

No predomínio do positivismo escolar, o escalonamento foi a tendência predominante. O objetivo de Vaz Ferreira era introduzir a força educacional da outra tendência, a da penetrabilidade. A única condição para um material ser pedagogicamente valioso é que ele seja parcialmente inteligível. Se fosse totalmente ininteligível, não haveria possibilidade de 
penetrabilidade e se fosse totalmente inteligível, não poderia acomodar a ação fermental (termo que Vaz Ferreira utilizava para se referir ao pensamento criador, germinador, que gera fermentação). Em relação à ideia de penetrabilidade, Vaz Ferreira destacou a importância de estímulos livres para a formação de uma personalidade que busque, por iniciativa própria, ampliar seus horizontes culturais:

O espírito que é educado sob uma disciplina fértil, tem em todos os momentos de sua evolução, em torno do círculo de conhecimento adquirido, uma penumbra de ideias, de sugestões, de hipóteses; além de saber, vislumbra, sente; daí seu progresso contínuo, mesmo sem novos estudos; a partir daqui, também, sua modéstia. (VAZ FERREIRA, 1963b, v. 177, p. 56, tradução nossa).

Buscar essa ação fermental, propriedade de todo material penetrável, é o que para Vaz Ferreira é um dos propósitos mais importantes de qualquer ação educacional. Para aprofundar o significado de cada ideia diretriz, Vaz Ferreira faz uma análise sobre como pensamos:

[...] recordemos previamente que a inteligência pode assimilar o conhecimento de duas maneiras: 1) pela assimilação completa e sucessiva das partes; 2) pela apreensão do conjunto, que, embora vaga e imperfeita no início, vai se concretizando, esclarecendo e completando posteriormente. De acordo com os casos, ou de acordo com o temperamento, os alunos usam uma ou outra dessas duas maneiras de aprender; [...] esquecer ou não levar em conta que a última forma de assimilação é possível, pode levar a exagerar na adaptação, na graduação, no ajustamento. (VAZ FERREIRA, 1963b, v. 17, p. 44-45, tradução nossa).

Pelo sofisma eterno da falsa oposição, poderíamos estar inclinados a um sermão ou uma declamação contra a educação formal, contra o texto e programas contra a aulas regulares, contra o trabalho metódico contra a tarefa diária de todos os professores que anotam e elaboram suas aulas [...] O mal (do qual eu desejo falar) não é fazer isso, mas o de não fazer mais do que isso. (VAZ FERREIRA, 1963b, v. 17, p. 72 , tradução nossa).

As regras absolutas são, na opinião de Vaz Ferreira, o resultado de uma sistematização prematura. Deste modo, ele oferece uma análise das consequências de falsas simplificações. Elas são, por um lado, "[...] a tendência para produzir conceitos distorcidos ou exagerados, mesmo assumindo boas ideias." (VAZ FERREIRA, 1963b, v. 17, p. 221-222, tradução nossa). Por outro, “[...] a criação ou fortalecimento do estado de espírito dogmático." (VAZ FERREIRA, 1963b, v. 17, p. 221-222, tradução nossa). Ele acrescenta uma terceira: "Obviamente, se eu acredito que, como resultado de uma dessas sistematizações de caráter absoluto em que tudo me é dado como resolvido, eu possuo a verdade, a minha curiosidade morre.” (VAZ FERREIRA, 1963b, v. 17, p. 221-222, tradução nossa).

\section{PLURALIDADE E MODOS DE CONHECIMENTO}

O entendimento de Vaz do papel da razão no espírito humano implica a existência de uma pluralidade de modos de conhecimento e também a sua distribuição por diversos níveis que correspondem a graus diferentes de racionalidade. Qualquer conhecimento combina 
elementos racionais com outros extrarracionais, mas nem todo conhecimento os combina da mesma maneira. Há uma ampla gama, de um controle racional rígido ao desempenho livre das forças extrarracionais, na qual as diferentes ciências estão distribuídas. Essas ciências começam com as matemáticas e terminam as ciências humanas, e, então, as profundidades diferentes do pensamento filosófico, que vão desde o mais sistemático ao mais "vivido".

Vaz não privilegia nenhum tipo de conhecimento ou inquirição nessa disposição pois cada um deles possui as suas próprias vantagens e desvantagens. Por exemplo, a sua crítica das ciências não envolve nenhuma aversão as mesmas, mas é somente uma denúncia da estreiteza do positivismo e do cientificismo em geral, pelos quais a ciência é a única abordagem da realidade que é válida. Outros modos de conhecimento não permitem a razão ser tão precisa e efetiva. A razão pode ser contrabalanceada pela ação de forças extrarracionais, perdendo, então, a sua precisão, mas adquirindo outros valores em troca. Quando a filosofia, com ciúmes do sucesso científico, busca para si a mesma precisão como aquela das ciências, comete um erro. A filosofia não necessita imitar as ciências neste aspecto porque possui outros privilégios: a vantagem da filosofia sobre as ciências é que ela lida com menos precisão, mas em um nível mais profundo - com os problemas vitais que realmente interessam aos seres humanos.

Vaz Ferreira ilustra os níveis diferentes de conhecimento, abrangendo desde o mais racional ao menos racional e correspondentemente da precisão à confusão, usando o mar como uma metáfora:

Nós podemos representar o conhecimento humano como o mar, a superfície é bem facilmente vista e descrita. Sob a superfície, a visão se torna, naturalmente, menos e menos clara; até, em uma região profunda, que não se pode mais ver: só se pode ver parcialmente - e, em uma região mais profunda ainda, parar-se-á de ver completamente. (VAZ FERREIRA, 1963b, v. 4, p. 151, tradução nossa).

O caráter sistemático e claro das ciências é contrastado com o caráter naturalmente menos rígido e menos transparente da filosofia. Vaz escreve sobre "[...] pensar por sistemas [...]" e "[...] pensar por ideias para se ter em conta [...]" como dois estados opostos da mente que correspondem ao modo de trabalhar dos cientistas e filósofos, respectivamente. (VAZ FERREIRA, 1963b, v. 4, p. 154-185). O estado sistematizado da mente é caracterizado pela tendência de tomar uma ideia e torná-la uma regra fixa para ser aplicada em toda circunstância e resolver qualquer tipo de problema. Esse é o método que corresponde às ciências, particularmente às matemáticas e às mecânicas: há uma busca por regras gerais que possam ser aplicadas a cada caso particular, com nenhuma necessidade de renovar o raciocínio para cada problema que queiramos resolver. Esse procedimento pode ser aplicado quando o objeto de estudo não é muito complexo - quando um conhecimento completo é possível, quando a sistematização deste conhecimento é também possível e quando as coisas estudadas são estritamente repetíveis. (VAZ FERREIRA, 1963b). É fácil ver que há algumas áreas da realidade que não admitem esse tipo de tratamento, e são, portanto, menos aptas a serem estudadas cientificamente. 
O estado oposto da mente é caracterizado pela tendência de ser aberto às ideias até que se tenha a oportunidade de julgar uma situação concreta sem noções preconcebidas e, portanto, permitindo uma atuação livre e maior da inteligência. Esse modo de abordar a realidade é - ou deveria ser - o método característico da filosofia. Este é um dos sentidos do "pensar melhor" que Vaz prescreve como alguém que sabe como usar o pensamento quando não precisa da ajuda artificial de um sistema pré-fabricado, mas é capaz de examinar cada caso particular por conta própria. Para pensadores, sistemas oferecem uma aparência ou sensação de segurança, mas eles deturpam a situação, pois os sistemas tendem a tratar em uma maneira rígida e fixa algo que na verdade é fluido e multifacetado. Eles, portanto, oferecem respostas sim/não para problemas da vida que na verdade requerem graus diferentes. Este é um simples pensar inteligente. Muitos problemas na vida necessitam ser abordados com uma variedade de ideias ao mesmo tempo, levando todas elas em conta, pesando cada uma delas e agindo com senso. "Uma questão de grau não pode ser resolvida de uma maneira geométrica." (VAZ FERREIRA, 1963b, v. 4, p. 175, tradução nossa). Tentar e aplicar um sistema já dado é simplesmente não pensar.

Comparado com as ciências, a filosofia possui um contato menos mediado com a realidade pois ela é capaz de abandonar os sistemas e esquemas fixos e explorar as coisas diretamente. Como a razão recompensa as ciências com a precisão, assim também as forças extrarracionais recompensam a filosofia com um contato próximo com a realidade. Em alguns lugares Vaz usa a luz como uma metáfora para a realidade, em um aparente paradoxo ele opõe a luz à claridade: ele fala sobre a "confusão luminosa" que reina nos níveis mais profundos nos quais os sistemas perdem seu sentido porque o espírito humano está em contato direto com a realidade. Ao contrário, o domínio das ciências, nos quais tudo é definido, é um âmbito de construções fictícias: elas ganham claridade, mas elas perdem a luz da realidade.

\footnotetext{
Quando nossa inteligência enfoca uma região qualquer do conhecimento e analisa a fundo, ocorre algo parecido ao que acontece quando, depois de se ter observado a olho nu, vamos aplicando instrumentos de potência crescente a uma parte qualquer do céu. Ali onde não víamos mais que alguns pontos de luz em uma localização certa e de fácil descrição, vão aparecendo outros novos em progressão hipergeométrica; ao final, tudo é uma espécie de confusão luminosa: - enquanto mais luz mais confusão ; e quando chegamos ali, sistemas já perderam os seus sentidos há tempo, pois eles, como as hidras, os dragões e os demais mitos dos céus, não eram mais que construções imaginativas fictícias que passavam pelos pontos mais visíveis. (VAZ FERREIRA, 1963b, v. 10, p. 153, tradução nossa).
}

Todas as ciências, não importa quão bem-sucedida ou suscetível a aplicação prática, são somente instrumentos limitados que podem somente oferecer um guia para a realidade, não uma descrição da mesma. Elas não são espelhos que podem refletir a real estrutura do mundo. De fato, a realidade não é estruturada, mas fluida: esta é a base ontológica da ideia anti-positivista de ciência de Vaz. A rigidez da abordagem científica não pode ser a única maneira de lidar com a realidade plástica, e certamente não é a melhor maneira. Uma boa maneira seria tão plástica e fluida quanto as coisas estudadas. É por isso, finalmente, que o 
contraste entre as ciências e a filosofia podem ser caracterizadas em termos de solidez versus fluidez.

A diferença entre ciência e filosofia é que a primeira é uma estrutura rígida baseada em bases firmes: sistemas e fórmulas que são aplicadas a cada caso particular e termos com significados fixos que são usados em um plano definido de abstração sem necessidade de outras análises mais apuradas. Ao contrário, a filosofia é mais fluida, pois ela aborda a realidade de uma maneira mais direta. Ou seja, menos delimitada por esquemas fixos. Por outro lado, falta à filosofia uma base firme, pois qualquer ideia pode ser tomada por muitos graus diferentes de abstração, correspondendo a diferentes níveis de análise. Enquanto que a ciência é uma área segura, a filosofia sacrifica a segurança pela plasticidade. (VAZ FERREIRA, 1963b).

Vaz prefere entender o pensamento filosófico em termos de "planos mentais" ao invés de em termos de "teses". Uma tese é uma formulação verbal que simplifica a situação que está sendo considerada, mas uma única tese pode ser pensada em diferentes planos mentais, que são complexos estados da mente que se combinam entre si e oferecem uma aproximação mais fiel as coisas reais. Como pode ser esperado, isto tem as suas consequências concernentes à noção de verdade. Uma dada formulação verbal pode mudar a sua verdade quando é considerada em um pano mental diferente. Ou seja, em graus diferentes de abstrações, dependendo de onde se decide parar a análise das pressuposições básicas. Sem ser um relativista - "nem tudo é plástico", Vaz alega, contra o pluralismo extremo de James. Vaz considera que a verdade e falsidade de formulações verbais são sempre relativas a um grau de abstração.

Em consequência, qualquer disciplina precisa tornar explícito o seu nível de abstração antes que possa declarar a verdade ou falsidade de uma sentença. Mas, de novo, as variedades de conhecimentos se comportam de maneiras diferentes. Nas ciências, a região da claridade, é muito fácil saber o nível de qualquer reivindicação pois é estabelecido explicitamente desde o início. Na filosofia, a região do conhecimento onde se pode somente ver parcialmente, é difícil distinguir os diferentes níveis de abstração. A tendência irrefreável de analisar cada vez mais profundo mantêm a filosofia constantemente se movendo de um nível ao outro. Isso explica o desacordo comum entre filósofos, pois tanto o significado das palavras e os níveis de abstração mudam e com eles, imperceptivelmente, o valor de verdade das teses. (VAZ FERREIRA, 1963b) ${ }^{12}$.

Para um entendimento adequado da relação entre ciência e filosofia, é necessário retomar uma das ideias principais de James que Vaz Ferreira admira: a concepção do pensamento humano como um "fluxo" (JAMES, 1950). A partir desta perspectiva é fácil entender a desconfiança de Vaz de qualquer sistema, mas também a sua atitude cuidadosa referente aos escritos e aos livros, que petrificam o ato naturalmente fluido do pensamento. (VAZ FERREIRA, 1963b). Apesar da ideia de solidez ter sido usada para caracterizar o modo científico do pensamento, tomar essa imagem literalmente abre uma divisão aguda entre 
ciência e filosofia. A divisão é irreal pois se esquece do papel desempenhado pelas forças extrarracionais cujas ações oferecem um caráter "plástico" a qualquer pensamento humano.

Usando mais uma metáfora, Vaz Ferreira compara a ciência com um iceberg no meio do oceano. Essa metáfora ilustra o contraste entre a ciência e a filosofia por comparar um pensamento mais sólido com um mais fluido. Ainda levanta a questão de que não há uma separação estrita entre ciência e filosofia, pois "[...] em todos os lados você encontra água, e se você for profundamente em qualquer lugar, você encontrará água.” (VAZ FERREIRA, 1963b, v. 10, p. 137, tradução nossa). Além disso, a ciência e a filosofia são momentos do mesmo fluxo do conhecimento humano e "[...] se você analisar qualquer porção do iceberg, vai descobrir que é feito também de água." (VAZ FERREIRA, 1963b, v. 10, p. 137, tradução nossa).

Se o espectro do conhecimento humano é um continuum no qual cada tipo de conhecimento escava mais fundo na realidade sem parar, então os limites entre ciência e filosofia não são precisos. A diferença entre ciência e filosofia não é de essência, mas de grau. É uma questão de nível de análise. Por exemplo, um cientista estuda o movimento usando a noção de força, então analisa essa noção de força, mas assume os dados sensoriais sem análise; além disso, o cientista pode analisar os dados anteriormente assumidos e, portanto, inevitavelmente e quase sem perceber, ele está se aproximando da filosofia e então prossegue através de níveis mais e mais profundos. (VAZ FERREIRA, 1963b).

Vaz Ferreira afirma que se você começa a pensar você não tem como escapar de ir mais fundo: "A ciência emite a fillosofia." (VAZ FERREIRA, 1963b, v. 2, p. 69, tradução nossa). Não há uma fronteira entre a ciência e a filosofia. Você pode parar de pensar por questões práticas, decidindo simplesmente usar as ferramentas científicas sem analisá-las. Mas se você não parar, então o pensar vai gradualmente conduzi-lo a problemas filosóficos. $\mathrm{O}$ matemático quando tentando clarificar a noção de infinito, o físico quando tentando clarificar a noção de matéria, o biólogo quando tentando clarificar a noção de vida - estão todos filosofando. Alguns cientistas são tendenciosos contra a filosofia, então, procuram fazer uma ciência "pura", mas eles não podem evitar considerar os problemas filosóficos que a ciência levanta.

A relação ideal entre a ciência e a filosofia é uma de cooperação. "A ciência real e a filosofia real, em toda a sua profundidade, trabalham em continuidade, não opostas, mas vinculadas." (VAZ FERREIRA, 1963b, v. 10, p. 222, tradução nossa). Entre a "ciência pura" e a "filosofia pura" há alguns níveis intermediários de conhecimento que servem como passagens que tornam a colaboração mais fácil. Os cientistas passam por esses níveis quando eles analisam além da ciência pura, tentando clarificar as noções que eles usam, tais como infinito, matéria e vida. Os filósofos também passam por esses níveis quando eles se voltam às ciências buscando novos assuntos para discussão, tais como a natureza do tempo ou o problema do indeterminismo, levantado pelo desenvolvimento das ciências. Vaz afirma tanto 
que a "[...] filosofia emana das ciências [...]" e que a "[...] filosofia as excita e fertiliza." (VAZ FERREIRA, 1963b, v. 13, p. 268) ${ }^{13}$.

Neste contexto, ao valorar a contribuição destes dois modos cooperativos do conhecimento humano, Acosta (1996, p. 154, tradução nossa) sustenta que "[...] filosofar é certamente em Vaz Ferreira, um modo de pensar. Mas esse modo de pensar é articulado de um modo, não externo nem artificial, com um modo de sentir e com um modo de agir." Podemos dizer que Vaz Ferreira, no campo educacional, vinculou a pedagogia à filosofia. De Giorgi (1972, p. 24, tradução nossa) argumenta que "[...] é difícil traçar uma linha divisória entre a pedagogia e filosofia [...]" no pensamento de Vaz. Ele acrescenta: "Toda filosofia culmina em pedagogia, dizia Dilthey, mas Vaz Ferreira era diferente, não havia nenhuma culminação, mas a convivência constante entre filosofar e educar; para ele, elas eram a mesma coisa." (DE GIORGI, 1972, p. 24, tradução nossa).

Finalmente, a articulação da ciência e da filosofia é uma consequência natural da unidade do conhecimento humano. $\mathrm{O}$ iceberg científico é feito de água assim como o oceano filosófico: "A ciência é metafísica solidificada." (VAZ FERREIRA, 1963b, v. 10, p. 137, tradução nossa). A solidez da ciência é artificial, o resultado da decisão de parar a análise em um certo ponto e usar certos dados como se esses fossem absolutos. Mas na realidade, qualquer "fato" esconde muitas hipóteses, sendo assim, a rigidez aparente é tão plástica quanto qualquer conhecimento humano. Vaz argumenta contra a oposição falsa entre humanidades e ciências que, às vezes, conduz ao desprezo de uma ou de outra na educação. Contra ambos os lados da falsa oposição, Vaz afirma que "Todo conhecimento é humano, da Filosofia ou História, à Matemática ou Biologia, e todo conhecimento, apesar dos detalhes de suas especializações, não somente não deve ser isolado, mas não pode ser isolado, sem deficiência, degeneração e dano." (VAZ FERREIRA, 1963b, v. 13, p. 268, tradução nossa) ${ }^{14}$.

As ciências e filosofia são legítimas e cada uma tem seu lugar na vida do pensamento humano. As ciências são o terreno da precisão e sistematização. Têm demonstrado serem muito úteis com respeito a aspectos da realidade que podem ser capturados em molduras rígidas. Mas a realidade não se reduz às sistematizações e, felizmente, o conhecimento não se reduz à ciência pura.

Contra o positivismo, Vaz elabora uma defesa da metafísica como "a forma mais alta da atividade do pensamento humano" e rejeita qualquer tentativa de torná-la "científica". O lugar da filosofia em geral e da metafísica em particular é o terreno da falta de precisão. Esta é precisamente a razão pela qual a filosofia pode auxiliar a ciência. Como um artista que desenha seus primeiros esboços e, então, os borra com sombras, minimizando a rigidez inicial, assim a filosofia neutraliza os efeitos dos sistemas rígidos estabelecendo relações, fazendo transições, permitindo confusões, entre outras coisas. (VAZ FERREIRA, 1963b, v. 10, p. 134, 164, 171). Vaz contrasta a precisão dos esquemas com a profundidade da análise, mas mantêm o lugar de ambas no conhecimento humano. 
Voltando-nos ao contexto da educação, por sua própria concepção de conhecimento, especialmente do ensinar a pensar, Vaz pondera sobre a diversidade de opiniões dos professores e que aqueles que são educados recebem ideias de pessoas com diferentes critérios. Este é o nosso conhecimento, imperfeito, cheio de lacunas. "Triste é que elas existam, sem dúvida; mas, dada a existência delas, é melhor conhecê-las do que ignorá-las." (VAZ FERREIRA, 1963b, v. 12, p. 192, tradução nossa). A atitude dogmática de acreditar na possibilidade da posse da verdade, da unidade do conhecimento e dos critérios epistemológicos indubitáveis, corresponde ao estado mental equivocado denominado por Vaz de simplismo.

Outras desvantagens e perigos de evitar a pluralidade do conhecimento no processo de educacional, de acordo com o pensador uruguaio, são que reforça a obsessão com o método único e o excesso de artificialidade no ensino, o que contribui para a perda da espontaneidade natural que é necessária para ensinar. Por outro lado, vinculado com a abstração e o esquecimento do mestre situado, gera "[...] uma certa tendência para perder a sensação de realidade pela preparação excessiva das lições de aulas destinadas a implementar - no papel preceitos excessivamente simplistas." (VAZ FERREIRA, 1963b, v. 12, p. 203, tradução nossa).

Como consequência dessa falta de espontaneidade relativa no ensino, que a autoridade do sistema tendia a produzir, Vaz Ferreira observou um embotamento do chamava de sentido da criança. O sentido da criança é uma certa sensação de poder ou atitude simpática, quase instintiva - que o professor percebe como temperamento, em maior ou menor grau, e é fortalecido pela experiência - de se sentir em qualquer dado momento o que a criança pode entender, o que não pode entender, o que vai responder, aonde vai chegar se lhe disser isto ou aquilo, "[...] se vai descobrir ou não o que se quer que ela busque; e tudo isso é como algo instintivo: não pode ser reduzido a preceitos, mas é sentido, quando o professor ensina de maneira muito natural e espontânea; se não, tende a embotar-se." (VAZ FERREIRA, 1963b, v. 12, p. 202, tradução nossa).

O verdadeiro espírito da educação e da pedagogia, o que deve apontar para penetrar cada vez mais, é o de remover todas as inibições, todos impedimentos, de seguir cada vez mais eliminando a "[...] crença ou sensação de que há uma série de coisas proibidas por princípios absolutos, mesmo quando o senso comum ou a espontaneidade ou simpatia lhes solicitem." (VAZ FERREIRA, 1963b, v. 12, p. 230, tradução nossa).

Assim, podemos dizer que a inimizade de Vaz em relação ao "pragmatismo" é na verdade uma reação contra o voluntarismo e relativismo de James. Vaz está preocupado que a crítica de James da certeza racional conduz ao extremo oposto. O reconhecimento que James faz da plasticidade do universo pode também ser levado a um extremo, a uma negação de qualquer verdade estável. Novamente, Vaz propõe um caminho intermediário, o que ele às vezes chama de "pragmatismo bom", e às vezes de "ceticismo bom". (VAZ FERREIRA, 1963 b, v. 8, p. 32, tradução nossa). Ao contrário do racionalismo que é satisfeito somente com 
a certeza da razão estrita, mas também como o "pragmatismo ruim" que reduz a certeza às forças da vontade, ele sugere uma gradação na confiança em nossas crenças e admissão da própria ignorância:

Saber o que conhecemos, e em qual nível de abstração que o conhecemos; acreditar quando devemos acreditar, no grau que devemos acreditar; duvidar quando devemos duvidar, e graduar nosso parecer com a precisão que está a nossa disposição; e, neste estado de espírito, agir em direção que achamos bom, pelas certezas ou pelas probabilidades, como adequado, sem forçar a inteligência, para não causar danificar este instrumento já muito imperfeito e frágil - e sem forçar a crença. (VAZ FERREIRA, 1963b, v. 8, p. 23, tradução nossa).

Isto está em perfeita harmonia com o espírito do pragmatismo clássico, que de acordo com Jaime Nubiola possui três aspectos centrais: anti-cartesianismo, falibilismo e pluralismo. (NUBIOLA, 2001).

Primeiro, Vaz rejeita o racionalismo moderno e seu subproduto, o cientificismo. Ele está ciente dos limites da razão e, então, recusa as dicotomias aparentes que esta impõe sobre o assunto da experiência do dia a dia. Ao invés de divisões rígidas entre categorias opostas, Vaz fala sobre graus e sombras que fazem a realidade - e nosso entendimento dela - menos rígida e artificial. A ciência não se opõe à fillosofia, a verdade e a falsidade pertencem as frases em uma determinada extensão, a razão se alia com profundidades não-racionais da mente e o conhecimento é, na verdade, um espectro amplo da ignorância à certeza que passa através da dúvida e crença. (COSTÁBILE, 1993).

No que tange à educação, Vaz Ferreira demonstrou a artificialidade científica do sistema educacional e escolar tradicional, o seu exagero de seus exclusivismos; provou que o trabalho escolar, sujeito meramente às leis, era forçado e necessariamente tortuoso. Assim, Vaz Ferreira mostrar novas direções e, sobretudo, insiste na relatividade de processos e leis psicológicas e pedagógicas. (CASTRO, 2007). É óbvio que nenhuma época e contexto está livre do perigo do exclusivismo. Deste modo, para enfrentá-los, é útil recuperar o pensamento de Vaz Ferreira pela sua relevância permanente.

Segundo, se o avanço do conhecimento não é uma história de acumulação triunfante de certezas, mas, ao invés disso, uma história de encontrar nosso caminho através das dúvidas e dos graus da certeza através da ignorância e do erro, por tentativas e autocorreções, então, Vaz aconselha construir um conhecimento por aproximações sucessivas: uma primeira tentativa e uma quantidade de correções subsequentes. Este é o método das ciências: as ciências são essencialmente incompletas, estão em crescimento e são incertas. A perfectibilidade e o progresso definem a ciência, mas essa é também uma característica do conhecimento humano em geral. Vaz defende um "pragmatismo sincero" que consiste de um esforço constante para clarificar os pensamentos iniciais, corrigir tentativas de soluções e retificar tentativas errôneas. (VAZ FERREIRA, 1963b, v. 10, p. 30).

Uma das críticas substanciais que o filósofo uruguaio faz à pedagogia de seu tempo é que ela fica em um nível puramente teórico, onde as inclinações para uma ou outra tendência 
são dadas por motivos de ordem subjetiva quando "[...] não deveria ser aceito, em matéria de ensino, uma única verdade que tenha sido experimentada." (VAZ FERREIRA, 1963b, v. 12, p. 233). Ele compara isso a um remédio sem testes clínicos. "E o engraçado é que, se nós, funcionários e professores, tivéssemos o hábito de submeter questões pedagógicas à experimentação, não faríamos nada menos do que uma revolução na educação global." (VAZ FERREIRA, 1963b, v. 12, p. 233). A principal razão para essa necessidade está na natureza da pedagogia, ela ainda não é uma ciência (dedutiva), de modo que a experimentação é sua fonte de conhecimento. Isso deveria ser apresentado na autopercepção do professor. A partir de sua formação e durante todo o seu trabalho é necessário levar em conta que não há regra ou sistema que explique tudo, que toda teoria é insuficiente e que a realidade não é transparente. "Não é a própria realidade que aprendemos: são esquemas simplificados." (VAZ FERREIRA, 1963 b, v. 4, p. 133, tradução nossa). Por isso, Vaz insiste que devemos sempre voltar à experiência vivida, ao contexto situado, a cada caso e aluno real, para de fato concretizar uma educação significativa e penetrante. A processo educacional de formação de professores deveria seguir a mesma lógica, pois

[...] mesmo que os estudantes de licenciaturas não devessem, no primeiro ano, orientar nem ensinar crianças, sempre deveriam ver: ver as escolas, estar na escola, ver as crianças da escola e professores, respirar a atmosfera da escola; para ver como é realmente ensinado, na escola real, por professores reais para crianças reais, de carne e osso; não as crianças inventadas pelo pedagogo de acordo com a psicologia e a lógica, ou com a sua psicologia ou lógica. (VAZ FERREIRA, 1909b, p. 3, tradução nossa).

Terceiro, o pluralismo é um rótulo que se encaixa muito bem na concepção de Vaz sobre o conhecimento. A pluralidade de faculdades que compõe o pensamento em um sentido amplo, a pluralidade dos pontos de vista que complementam um ao outro. A pluralidade de opiniões que devem ser confrontadas para se obter uma compreensão plástica da realidade plástica. A cooperação e o diálogo com outras pessoas e consigo mesmo, assim como o falibilismo e o pluralismo, são elementos essenciais na construção do conhecimento. A rejeição de Vaz das categorias simplistas; sua insistência sobre o valor da dúvida, contradição e erro; e a sua concepção cooperativa de conhecimento, todas apontam para a verdade como algo sempre buscado e as vezes parcialmente alcançado. (LOCKHART, 1999). É, portanto, coerente afirmar que a estes posicionamentos de Vaz Ferreira, que constituem a sua filosofia, expressam uma visão pragmatista do conhecimento.

\section{CONSIDERAÇÕES FINAIS}

Consideramos que um dos possíveis caminhos para aprofundar os nossos conhecimentos sobre nós mesmos, a nossa realidade e condição humana está em aprofundar o pensamento e as contribuições de filósofos latino-americanos. Ao explorarmos as conexões entre o filósofo uruguaio e educador Carlos Vaz Ferreira e o pragmatismo consideramos que ele foi um dos primeiros latinos que leu sobre esta corrente filosófica. Em 1909 Vaz Ferreira 
publicou El Pragmatismo, o primeiro livro em espanhol dedicado ao pragmatismo. A despeito do caráter crítico de suas obras, a presença de James no pensamento de Vaz é reconhecida em vários lugares. Vaz Ferreira está muito próximo dos problemas e abordagens características do pragmatismo norte-americano. Por exemplo, em seu reconhecimento de certas tendências positivas do pragmatismo, Vaz mostra um profundo acordo que subjaz os desacordos com James.

Vaz compartilha com James a ideia de que a organização e o controle são obtidos com um alto custo. Os sistemas racionais e classificações somente dividem o continuum, simplificam o complexo e reduz o ilimitado à um tamanho prático, perdendo, portanto, as riquezas da realidade. Além disso, observamos que a noção de psiqueo, usada por Vaz, mostra a afinidade dele com as ideias de William James e Henri Bergson. O termo psiqueo de Vaz aproxima-se da ideia de um "fluxo do pensamento" de James, pois ambos se opõem à uma concepção descontínua do pensamento que emerge de uma identificação errônea do pensamento com a linguagem. Assim, o entendimento de Vaz do papel da razão no espírito humano implica a existência de uma pluralidade de modos de conhecimento e também a sua distribuição por diversos níveis que correspondem a graus diferentes de racionalidade. Concluímos que a ocasional inimizade de Vaz em relação ao "pragmatismo" é na verdade uma reação contra o voluntarismo e relativismo de James. Vaz está preocupado que a crítica de James da certeza racional possa conduzir ao extremo oposto. Vaz, assim, propõe um caminho intermediário, o que ele às vezes chama de "pragmatismo bom". Isso está em perfeita harmonia com o espírito do pragmatismo clássico em três aspectos centrais, o anticartesianismo, o falibilismo, e o pluralismo.

Todas essas aproximações, observadas neste trabalho, que manifestam conexões profícuas entre o pensamento latino-americano e o pragmatimo caracteriza um ambiente gradual, mais pluralístico, na filosofia que ainda está se desenvolvendo e que abre a possibilidade de redescobrir as vozes e pensamentos as vezes deixados de lado da grande "conversação da humanidade". Seria de fato um erro pensar no desenvolvimento do pragmatismo e da filosofia latino-americana como totalmente isolados um do outro. Isto é, pudemos ver, ainda que de maneira limitada, que há pontos de intersecção entre desenvolvimentos lineares na história das tradições filosóficas e que estudar estes pontos de intersecção pode render importantes lições. Como, por exemplo, que no diálogo entre as tradições de pensamento nas Américas manifesta-se a preocupação com a experiência vivida prática, considerada a fonte e o ponto de partida para todo o filosofar. Além disso, nesse diálogo se constitui a concepção do indivíduo como um todo orgânico e ativo em relacionamentos sociais e a importância da educação se torna evidente como um processo para viver no presente e transformar a sociedade em uma direção democrática.

Finalmente, Vaz Ferreira não oferece uma teoria educacional e pedagógica acabada a partir da qual sejam inferidos dedutivamente preceitos, mas afirma que a tarefa pedagógica consiste na análise crítica de práticas de ensino que constituem uma tendência, geralmente 
seguidas de maneira acrítica. A pedagogia de Carlos Vaz Ferreira propõe a aplicação de diretrizes levando em consideração cada caso. Pondera a simpatia/sensibilidade do professor como um elemento chave no ensino. Leva em consideração a pluralidade de modos de conhecimentos para abarcar a pluralidade complexa do mundo. Incentiva a sinceridade e transparência do docente em seu trabalho, visando sempre o processo de aprendizagem acima do resultado, a compreensão acima da rotina. Vaz Ferreira recomenda a discussão sempre viva e a incorporação saudável do corpo e de todas as dimensões e expressões constituintes do ser humano à aprendizagem, cujo contexto situado é a natureza e a experiência vivida.

\section{REFERÊNCIAS}

ABOULAFIA, M. Habermas and pragmatism. London: Routledge, 2002.

ACOSTA, Y. El filosofar latinoamericano de Vaz Ferreira y su visión de la historia. In: ANDREOLI, M. (comp.). Ensayos sobre Carlos Vaz Ferreira. Montevideo: Universidad de la República-FHCE, 1996. p. 153-180.

ANDREOLI, M. (comp.). Ensayos sobre Vaz Ferreira. Montevideo: Facultad de Humanidades y Ciencias de la Educación, 1996.

ARDAO, A. La filosofia en el Uruguay en el siglo XX. Buenos Aires: Fondo de Cultura Económica, 1956.

ARDAO, A. Introducción a Vaz Ferreira. Montevideo: Barreiro y Ramos, 1961.

BERGSON, H. L. Introdução à metafísica. In: BERGSON, H. L. Cartas, conferências e outros escritos: textos selecionados. São Paulo: Abril Cultural, 1984.

BERNDTSON, A. Vaz Ferreira, Carlos. In: EDWARD, P. (ed.). The encyclopedia of philosophy. London: Macmillan; New York, 1967.

BRANDOM, R. B. (ed.) Rorty and his critics. Maldem, Massachusetts: Blackwell, 2000.

BROWNING, D. Dewey and Ortega on the Starting Point. In: PAPPAS, G. F. (ed.).

Pragmatism in the Americas. New York: Fordham University Press, 2011. p. 135-154.

CAMPOS, A. de. El problema de la creencia y el intelectualismo de Vaz Ferreira.

Montevideo: Universidad de la República, 1959.

CASTRO, J. EI banco fijo y la mesa colectiva. Montevideo: Ministerio de Educación y Cultura, Dirección de Educación, 2007.

COSTÁBILE, H. La ideia de razón en Vaz Ferreira. Anales de Enseñanza Secundaria, Montevideo, v. 3, n. 4, p. 12-17, 1993. 
DE GIORGI, D. El pensamiento pedagógico de Vaz Ferreira. Cuadernos de Marcha, Montevideo, n. 64, p. 23-30, ago. 1972.

DEWEY, J. Experience and nature. In: BOYDSTON, J. (ed.). The later works: 1925-1953. Carbondale: Southern Illinois University Press, 1981. v. 1.

DONOSO, A. John Dewey in Spain and in Spanish America. In: PAPPAS, G. F. (ed.).

Pragmatism in the Americas. New York: Fordham University Press, 2011. p. 19-39.

DURAN, J. Vasconcelos, pragmatism and the Philosophy of México. APA Newsletter on HIspanic/Latino Issues in Philosophy I, n. 1, p. 82-84, 2001.

DURRUTY, M. V. F. de. Recuerdos de mi padre: los últimos días de mi padre. Montevideo: Monteverde, 1981.

ECHEVARRÍA, S. V. F. de. Carlos Vaz Ferreira: vida, obra, personalidad. Montevideo: División Publicaciones, Ediciones de la Universidad de la República, 1984.

FLORES, R. John Dewey and the legacy of Mexican pragmatism in the United States. In: PAPPAS, G. F. (ed.). Pragmatism in the Americas. Fordham University Press, 2011.

GARCÍA, M. S. En torno a la libertad y el determinismo. Montevideo: Edición del Instituto Jung, 1989.

GRAHAM, J. T. A Pragmatist philosophy of life in Ortega y Gasset. Columbia: University of Missouri Press, 1994.

GOMEZ, M. A. Rediscovering the philosophical importance of jose ingenieros Thesis College Station: Texas A\&M University May 2006. 56 f.

HOOKWAY, C. Logical principles and philosophical attitudes: Peirce's response to James's pragmatism. In: PUTNAM, R. A. (ed.). The Cambridge Companion to William James. Cambridge: Cambridge University Press. 1997. p. 145-65.

HOROWITZ, I. L. Carlos Vaz Ferreira: a review of his Collected Works, The Hispanic American HIstorical Review, v. 40, n. 1, p. 63-69, 1960. Disponível em: http://www.jstor.org/pss/2509794. Acesso em: 23 out. 2018.

INGENIEROS, J. Hacia una moral sin dogmas. Buenos Aires: Losada, 1947.

INGENIEROS, J. El hombre medíocre. Ciudad de México: Azteca, 1963.

JAMES, W. Pragmatism. In: KUKLICK, B. (ed.). Writings, 1902-1910. New York: Library of America, 1987a. p. 479-624.

JAMES, W. Some problems of philosophy. In: KUKLICK, B. (ed.). Writings, 1902-1910. New York: Library of America, 1987b. p. 979-1106.

JAMES, W. The principles of psychology. New York: Dover, 1950. 2. v.

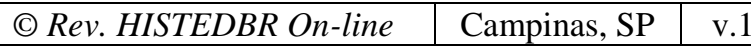


JAMES, W. The varieties of religious experience. New York: Longmans, Green and Co, 1902. Disponível em: http://www.archive.org/details/varietiesreligi02jamegoog. Acesso em: 13 nov. 2018.

JAMES, W. The Will to believe: and other essays in popular philosophy. New York: Longmans Green, 1897. Disponível em: https://ia802205.us.archive.org/12/items/thewilltobelieve00jameuoft/thewilltobelieve00jameu oft.pdf. Acesso em: 15 nov. 2018.

KALVELAGE, J. Paulo Freire and Dewey’s legacy. Edcentric, v. 27-28, p. 33-38, 1974.

LOCKHART, W. Vaz Ferreira o el drama de la razón. In: BRANDO, O. (ed.). El 900. Montevideo: Cal y Canto, 1999. p. 320-323.

MALVASIO, D. Sobre el pragmatismo de William James en la óptica de Vaz Ferreira. In: ANDREOLI, M. (comp.). Ensayos sobre Carlos Vaz Ferreira. Montevideo: Facultad de Humanidades y Ciencias de la Educación, 1996. p. 217-225.

MARTÍNEZ, I. William James y Miguel de Unamuno: una nueva evaluación de la recepción del pensamiento pragmatista en España. 2007. Tese (Doutorado) Universidad de Navarra, 2007. Disponível em: http://www.unav.es/gep/TesisDoctorales/TesisMartinez.pdf. Acesso em: 09 nov 2018.

MATO, C. Pensamiento uruguayo: la época de Carlos Vaz Ferreira. Montevideo: Fundación de Cultura Universitaria, 1995.

MEDINA, J. Pragmatism and ethnicity: critique, reconstruction, and the new hispanic.

Metaphilosophy, v. 35, n. 1-2, p. 115-146, 2004.

MENDIETA, E. Which pragmatism? Whose america? In: YANCY, G. (ed.). Cornel west: a critical reader. Malden: Wiley-Blackwell, 2001. p. 83-104.

NUBIOLA, J. Pragmatismo y relativismo: una defensa del pluralismo, Themata Revista de Filosofía, v. 27, p. 49-57, 2001.

NUBIOLA, J.; ZALAMEA, F. Peirce y el mundo hispânico: lo que C. S. Peirce dijo sobre España y lo que el mundo hispánico ha dicho sobre Peirce. Pamplona: Eunsa, 2006.

PAPPAS, G. F. El punto de partida de la filosofia en Risieri Frondizi y el pragmatismo, Anuário Filosófico, v. 40, n. 2, 2007.

PAPPAS, G. F. (ed.). Pragmatism in the Americas. New York: Fordham University Press, 2011.

PÉREZ-ILZARBE, P. Vaz Ferreira as a pragmatist: the articulation of science and philosophy. In: PAPPAS, G. F. (ed.). Pragmatism in the Americas. New York: Fordham University Press, 2011. 
ROMERO BARÓ, J. M. Filosofía y ciencia en Carlos Vaz Ferreira. Barcelona: Promociones y Publicaciones Universitarias, 1993.

ROMERO BARÓ, J. M. Carlos Vaz Ferreira (1872-1958). Madrid: Ediciones del Orto, 1998.

RORTY, R. M. Philosophy and the Mirror of Nature. Princeton: Princeton University Press, 1979.

SHOOK, J. R.; MARGOLIS, J. (ed.). A Companion to Pragmatism. Malden, MA: Blackwell, 2006.

VAZ FERREIRA, C. Conocimiento y Acción. Montevideo: Cámara de Representantes de la República Oriental del Uruguay, 1963a.

VAZ FERREIRA, C. El Pragmatismo. Montevideo: Tipografía de la Escuela Nacional de Artes y Oficios, 1909a.

VAZ FERREIRA, C. En los márgenes de "I'Expérience religieuse", de W. James. Montevideo: Mariño y Caballero, Impresores. 1908.

VAZ FERREIRA, C. Informe de abril 15, Montevideo. A.H.II.N.N. Archivo Histórico de los Institutos Normales, Fondo Instituto Normal de Señoritas, v. 12, p. 3-8, 1909 b.

VAZ FERREIRA, C. Informe de enero 2, Montevideo. Comunicado. n. 4210, enero 30 de 1904. Archivo Histórico de los Institutos Normales, Fondo Instituto Normal de Varones, 1904.

VAZ FERREIRA, C. Obras de Carlos Vaz Ferreira. Montevideo: [Cámara de Representantes de la República O. del Uruguay], 1963b. 25 v.: ill., ports., facsims.

VAZ FERREIRA, C. Tres filósofos de la vida: Nietzsche, James, Unamuno. Buenos Aires: Losada, 1965.

\section{Notas}

\footnotetext{
${ }^{1}$ Docente e pesquisador do Centro Universitário Leonardo Da Vinci (UNIASSELVI), membro do grupo de pesquisa Filosofia e Educação EDUCOGITANS (FURB).E-mail: kevinleyser@gmail.com

${ }^{2}$ Docente e pesquisador da Universidade Regional de Blumenau (FURB), pesquisador do Grupo Educogitans da FURB, Observatório de Estudos Comparativos em Educação (OIECE), Grupo Paideia e Grupo de Estudos e Pesquisas em Política e Avaliação Educacional da Faculdade de Educação da UNICAMP. E-mail: ajemabra@yahoo.com

${ }^{3} \mathrm{Na}$ realidade, Einstein leu a tradução francesa desse livro na ocasião de sua visita, em 1925, a Montevidéu. Einstein escreveu para Vaz Ferreira agradecendo-o pelo presente, explicando que ele estava de acordo com Vaz sobre as incongruências nos usos da verdade entre os vários pragmatistas e adicionando: "Eu creio que o conceito de 'verdade' não pode ser tratado separadamente do problema da realidade". (VAZ FERREIRA, 1965, p. 198, tradução nossa). Uma tradução para o espanhol das anotações de Einstein sobre a sua visita em Montevideo e da carta de agradecimento que ele escreveu para Vaz Ferreira depois de receber o livro podem ser encontradas no
} 
endereço eletrônico: http://fp.chasque.net/ relacion/0008/mundanalia.htm. A carta foi reproduzida em facsimile no livro de Vaz Ferreira (1965).

${ }^{4}$ Arturo Ardao (1956) o descreve como o expoente principal da filosofia uruguaia do século vinte.

${ }^{5}$ Helena Costábile estudou as ideias de Vaz sobre a natureza da razão e âmbito da razão como uma ferramenta para o conhecimento.

${ }^{6}$ Como uma introdução à vida e ao trabalho de Carlos Vaz Ferreira, Cf. Matilde Vaz Ferreira de Durruty (1981); Sara Vaz Ferreira de Echevarría (1984); Arturo Ardao (1961); Arthur Berndtson (1967); M. Andreoli (1996); Carlos Mato (1995); José María Romero Baró (1998). Para ir direto à filosofia de Vaz Ferreira, a obra Fermentario pode ser a obra que melhor mostra o seu estilo e preocupações. A coletânea das obras de Vaz foi publicada em 25 volumes como um tributo pelo Governo Uruguaio. A primeira edição apareceu em 1957, e depois se ampliou em 1963. Uma revisão da primeira edição foi escrita por Irving Luis Horowitz (1960).

${ }^{7}$ A palavra "coisa" é também um esquema de realidade fluente, mas Vaz se permite usar o termo.

${ }^{8}$ Aqui se refere aos textos de Vaz: "Transcendentalizaciones matemáticas ilegítimas y falácias correlacionadas" que está nas Algunas conferencias sobre temas científicos, artísticos y sociales, no volume 11 e 12 de suas Obras (1963b); e ao "Pensar por sistemas y pensar por ideas para tener en cuenta" que está na Lógica Viva, no volume 4 de suas Obras (1963b).

9 Aqui se refere aos textos de Vaz: "Psicología y lógica de las classificaciones, y falacias verboideológicas relacionadas" que está nas Lógica viva, no volume 4 de suas Obras (1963b); e "Un paralogismo de actualidad" que está na Fermentario, no volume 10 de suas Obras (1963b).

${ }^{10}$ Aqui se refere ao texto de Vaz: "La crisis atual del mundo desde un punto de vista racional" que está nas Algunas conferencias sobre temas científicos, artísticos y sociales, no volume 11 e 12 de suas Obras (1963b).

${ }^{11}$ Aqui se refere a obra de Vaz Conocimiento y acción no volume 8 de suas Obras (1963b).

12 Aqui se refere a obra de Vaz Los problemas de la libertad y los del determinismo no volume 2 de suas Obras (1963b).

${ }^{13}$ Aqui se refere a obra de Vaz Sobre La enseñanza en nuestro país no volume 2 de suas Obras (1963b).

${ }^{14}$ Em harmonia com estas ideias Vaz lutou para criar a Faculdade de Humanidades e Ciências da qual ele foi o reitor por muitos anos. 